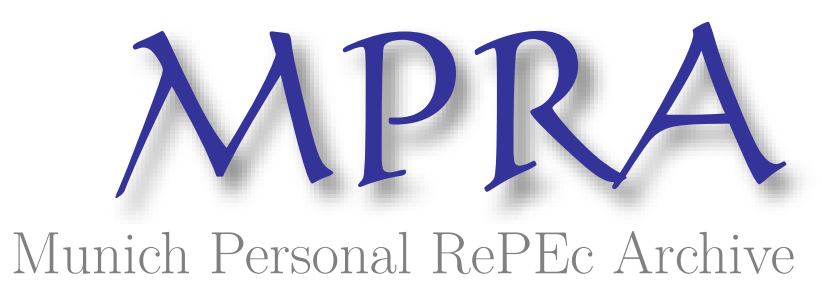

\title{
Reformed Pensions Systems in Central and Eastern Europe: Challenges to future safe pension benefits
}

Lazarevski, Dimche and Mrsik, Jadranka

University American College Skopje, Macedonia

May 2012

Online at https://mpra.ub.uni-muenchen.de/41996/

MPRA Paper No. 41996, posted 16 Oct 2012 20:56 UTC 


\title{
Reformed Pensions Systems in Central and Eastern Europe: Challenges to future safe pension benefits
}

\author{
Jadranka Mrsik PhD \\ Asst.Prof. at University American College \\ Skopje, Macedonia \\ jadranka.mrsik@uacs.edu.mk
}

\author{
Dimche Lazarevski PhD \\ Asst.Prof. at University American College \\ Skopje, Macedonia \\ lazarevski@uacs.edu.mk
}

\begin{abstract}
The objective of this paper is to examine and analyze empirically whether the Central and Eastern Europe countries`reformed pension systems are providing adequate and safe pensions. Starting in 1990s, most Central and Eastern European countries radically reformed their pension systems. The rising optimism initiates many studies where the advantages of the reforms were in the focus.

The global financial crisis negatively affects the reformed pension systems. As a response, the policy makers in few of those countries decided to set up different measures: increasing or reducing the pension contribution for alleviating the fiscal deficit or encouraging the employment, adapting the contribution rate and allowing individuals to switch back to the old system. These last changes in the pension systems have triggered the following question: How much and in which way the implementation and experiences gained with the functioning of the reform pension system will have impact in the future pension adequacy and sustainability of the pension system?
\end{abstract}

Keywords: reformed pension systems, financial crisis, sustainability of pension systems, government measures, pension contributions, pension benefits

JEL classification: G10, G23, H55, J26, J32 


\section{Introduction}

In Central and Eastern Europe (CEE), almost all countries have reformed their pension systems in the past two decades as a response to the population aging and fiscal pressures. Many of them have implemented the Chilean model; defined-contribution schemes based on individual pension savings accounts and adopted the multi-pillar pension structure. In the new system the first pillar that is mandatory and managed by the government, represents a pay-as-you-go scheme. The second pillar is mandatory also but based on a funded scheme, and the last pillar a funded one is voluntary.

Most of the studies are exploiting the reasons for the pension system reform, the design of the reformed system, the investment activities and its performance, and only few are paying attention to the capacity of the reformed system to provide its sustainability and adequate pensions to the population. However, those studies that examine the impact of the reformed pension systems to the amount of future pension have not included the Macedonian pension system in their researches. This is because Macedonian pension system is among the last reformed and the pension funds assets are still insignificant: in 2010, 2.9\% from GDP compared with $15.8 \%$ in Poland and $14.6 \%$ in Hungary, the leading pension reform countries among the CEE counties (Pension Markets in Focus No 8, July 2011).

In many EU countries, especially in the CEE countries, which have adopted the second pillar later than Latin American countries, the global financial crisis has raised questions concerning the benefit of switching to a mixed pension system, in comparison with the former one which relied exclusively on public pay-as-you-go schemes. The shocks to pension systems caused by the financial near meltdowns in 2008/2009 balanced, but the question remains how its effects are likely to linger with us in the decades to come, because of the 
long run character of the pension savings. Therefore, the beliefs in the future reliable pensions within the reformed pension systems in CEE countries are becoming questionable.

The aim of this paper is to assess the adequacy of prospective retiring income of Macedonia' current generations of workers to the retiring income of current retiree, and compare those results with those in the selected CEE countries (Poland, Hungary, Slovakia and Bulgaria). Pension system sustainability will also be in the focus of our analysis.

\section{Literature Review: The Impact of the Pension reforms on the future pension benefit}

Defining pension adequacy is clearly more controversial than defining pension sustainability. Whereas the definition of sustainability exposes the perception of actuarial fairness, there is different conception for the adequate pension systems. Some are concentrating on alleviation the poverty while others will say adequacy should cover both this poverty objective as well as the guarantee that pensioners can maintain a decent living standard or even a broader condition on the income distribution to pensioners (Draxler \& Mortensen, 2009). Various definitions also explain why there is a more long-standing tradition to focus on the sustainability of pension systems in the median and long term. Fornero and Vanriet (2005) recapitulate some definitions related to adequate pensions. The adequacy concept of a pension is defined as:"securely financed, adequate income that does not destabilize public finances or impose an excessive burden on future generations, while maintaining fairness and solidarity, and responding to the changing needs of individuals and society" (Social Protection Committee, 2000). "Public earnings-related schemes (first pillar), private occupational schemes (second pillar) and individual retirement provision (third pillar), provide good opportunities for most Europeans to maintain their living standards after retirement" provide adequacy (European Commission, 2002). Pension systems should 
"ensure that older people are not placed at risk of poverty and can enjoy a decent standard of living" and "enable people to maintain, to a reasonable degree, their living standards after retirement" (Laeken summit, 2001). At the Laeken summit (2001), the members of the EU-15 have fixed eleven objectives for pension systems with particular emphasis on three general targets: adequacy, financial sustainability and modernization. Three of the eleven objectives specially referred to the adequacy of pension systems: poverty among the elderly population, living standard smoothing after retirement and (intra and inter-generational) solidarity (EC, 2003). In this study, we are focusing on the definition of indexes for living standard smoothing after retirement.

As the number of pensioners in Europe rises in relation to the number of people in employment, ensuring adequate pensions on sustainable basis has became a major challenge. The wave of "pension privatization" was expanding during the last three decades (Brooks, 2005; Clark \& Whiteside, 2005; Ervik, 2005; Guardiancich, 2008; Kay \& Sinha, 2008; Madrid, 2003; Müller, 2001; Orenstein, 2008; Weyland, 2005), started as a regional trend in Latin America and Central and Eastern Europe in the 1990s, later spread to Africa and Asia. Pension reform cut the state provision for old-age retirement and increase individuals' responsibility (Hacker, 2006; Munnell \& Sass, 2007).

The global financial crisis of 2008-2010 seems to have ceased, at least temporarily, so there is a trend towards mandating savings in individual funded pension accounts worldwide, the core reform of the pension privatization trend. Since the crisis, not a single country has adopted mandatory individual accounts and several of them only have considered but not implemented.

Some of them have even taken some few specific actions in this respect (World Bank, 2009; Velculescu, 2011): some countries have modified the overall contribution rate, and some of them increased it in order to alleviate the fiscal deficit (e.g. Romania). Others have 
reduced it, with the aim of fostering the employment and incomes (e.g. Macedonia and Bulgaria). Several have frozen or adjusted differently in comparison with the prior calendar of the second pillar contribution rate (e.g. Estonia, Lithuania, Latvia, Romania, and Estonia). Moreover, more radical measures have been taken by some CEE countries, allowing individuals to switch back to the old system, getting out of the second Pillar (e.g. Hungary, Slovakia) or making the second pillar voluntary to new entrants on the labor market (e.g. Slovakia). Finally, they have taken some measures in order to prevent early retirement (e.g. Hungary, Poland, and Latvia) or they increase the retirement age limit (e.g. Hungary, Romania, and Poland).

Milos and Milos (2011) believe that all these actions taken by the authorities in order to alleviate the budget tensions are short-term solutions, thus the reform of the pension system must continue. Jarrett (2011) pointed out that trying to solve the problem of public finance sustainability by radically shrinking the second tier of the pension system has obvious costs in terms of poverty among old-age pensioners. Their benefits will be considerably lower than the ones of working age, and it will strongly affect their confidence in the multi-pillar system.

The current economic crisis is the first one since the pension reform implementation in the CEE countries. Earlier, the researchers focused mainly on the reformed pension systems' structures and pension funds' investment activities in the newly established second pillars. Since 2008, published are several works that examine the impact of the economic crisis on the pension systems financing in the CEE countries.

Future levels of pensions in relation to earnings (income replacement levels) will depend on different factors, notably the pace of accrual of pension entitlements (linked to evolutions in the labor market), the maturation of pension schemes and the effect of enacted reforms (European Commission, 2009). 
To explore the impact of the institutional setting and policy distance on pension implementation on the amount of the future pension benefits, we have studied four Central and East European countries that reformed their pension systems in the 1990s and early 2000s: Poland, Slovakia, Hungary and Bulgaria.

The two main official studies dealing with the calculation of replacement rates at retirement are those by the ISG (2006) and OECD (2007). In the report Current and Prospective Theoretical Pension Replacement Rates by the ISG (2004 and 2046), replacement rates are calculated for sample individuals to allow a comparison of similar work histories among different European countries. The sample individuals have a career pattern lasting 40 years, from the age of 25 to 65 , a full-time job and a salary steadily equal to $100 \%$ of the national average wage. Other common assumptions include the inflation rate and the formula to calculate pension and survivor's benefits.

In Pensions at a Glance 2007 (OECD, 2007), gross and net replacement rates are calculated for sample individuals entering the labor market at the age of 20 and working until retirement. Calculation of the gross replacement rate is for workers with incomes equal to the median and to $0.5,0.75,1,1.5$ and 2 times the national wage. Net replacement rates take into account the individual's taxation and paid contributions. The calculation of supplementary pension benefits assumes an annual actual return rate of $3.5 \%$, net of administrative costs. To compare replacement rates calculated by the ISG using a representative individual with sample-based replacement rates, the authors calculate replacement rates based on the first and the second pillars, net of taxes, and for men only.

Macedonia reformed its pension system in 2006, among the latest CEE countries that have made structural pension reform. The impact of the reformed pension system especially 
on the future retirees' incomes, we cannot precisely see for at least next 20 years ${ }^{1}$. However, by using the calculations for the replacement ratios in this paper we will try to answer approximately the previously touched dilemmas.

\section{Model and Data}

The issue of pension income adequacy (Zaidi, 2010) has not been a priority in pension reforms. During the initiation of the Macedonian pension reform, we have no evidence of a study that measure the expectations for obtaining higher pension benefit from the reformed pension system. Thus, this paper focuses on the current and future pensions for three groups of workers (low, average and above average earners), for those who stayed in the pay-as-yougo system and those who entered the reformed (three pillar) system.

We will use different ratios to evaluate how Macedonian and selected CEE Countries' reformed pension systems will affect pension levels in the future. To analyze the aggregate impact of pension reforms we will use the indicator 'Benefit Ratio', as calculated by the Working Group on Ageing of the EU's Economic Policy Committee. The Benefit ratio calculation:

$$
\frac{G A P B}{E G A W}=B R
$$

Where GAPB is the gross average pension benefit and EGAW is the economy wide gross average wage. GAPB calculation is:

$$
\mathrm{OAP}+\mathrm{EP}+\mathrm{SP}+\mathrm{DP}=\mathrm{GAPB}
$$

\footnotetext{
1 The first pensioners from the multi pillar pension system are expected in 2030, since the average age of members of the second pillar is 32 (Agency for supervision of fully funded pension insurance 2010 Report).
} 
Where OAP is the old-age pension, EP is the early pensions, SP is the survivor's pension, and DP is the disability pensions. Private pensions, statutory or occupational, are not included.

We will compare the calculated benefit ratio for Macedonia for 2007 and 2060, with the results for the selected CEE countries.

Then we will elaborate the pension income adequacy by examining how pension reforms have changed the structure of pension systems across EU countries. This impact of pension reforms results are derived from the simulations of pension income entitlements for future retirees, undertaken by OECD in 2009. For these calculations, we use the APEX (Analysis of Pension Entitlements across Countries) model infrastructure of the Organization for Economic Co-operation and Development $(\mathrm{OECD})^{2}$. To analyze the impact of the pension reforms on the structure of future pension system, we will calculate the changes in the 'Net Replacement Rate' before and after the pension reform for low, average (basic scenario) and above average workers wage. Calculation of Net Replacement Rate is:

$$
\frac{N P}{N A R W}=N R R
$$

Where NP is the Net Pension (gross pension, tax deducted), and NAW is the Net Average Real Wage calculated for 40 years.

NRR will be calculated using a case of a male worker who enter into employment during 2006 and will retire in 2046 and spent his full career working (40 years) in Macedonia, and then will be compared with those for the selected CEE countries.

Last but not the least; we will focus on the changes in the entitlement of public pension income during the period 2006-2046. The indicator in use is the 'Theoretical Replacement

\footnotetext{
2 Axia Economics originally developed the APEX (Analysis of Pension Entitlements across countries) model, with the help of funding from the OECD and the World Bank. The model codes detailed eligibility and benefit rules for mandatory pension schemes based on available public information that has been verified by country contacts. It provides most of the results reviewed in OECD "s biennial „Pensions at a Glance " publication (see OECD (2005), OECD (2007) and OECD (2009) and Whitehouse (2007).
} 
Rate' (TRR), as provided by the Indicators Sub-Group of the EU's Social Protection Committee (an $\mathrm{ISG}^{3}$ indicator). Theoretical Replacement Rate calculation in the base scenario is meant for a hypothetical person (male) employed in 2006, with a full working life (40 contribution years), retiring at 64 , and accumulating pension rights under the new mandatory pension scheme and divide by the projected wage in the immediate previous period (2045). We will compare this ratio with the theoretical ratio in 2006 for someone employed for the first time in 1966 and accumulating pension rights only under the PAYG system. It measures how reformed pension systems change future pension entitlements and it covers mandatory public and private pension schemes. We will compare the obtained TRR results with those of the selected CEE Countries.

Theoretical replacement rates, as stated in the EU Report for 2009, provide the possibility to look at individual case studies and evaluate to what extent current and future pension systems ensure adequate pensioners living standards. Furthermore, theoretical replacement rates provide different information than those obtained through the projection exercise of the Ageing Working Group (AWG) Economic Policy Committee. Their calculations of benefit ratios and replacement rates, project future benefits using assumptions such as the increases in women's participation, whereas theoretical replacement rates allow the possibility to study the singular effect of reformed pension rules on the adequacy of pension income (ISG Report, 2009). Borella and Fornero (2009) propose the use of a comprehensive replacement rate (CORE) for comparing the ability of different pension systems to enable individuals to maintain their living standards when retired, using the (CeRP) SAM simulation model (Ferraresi \& Monticone, 2009).

\footnotetext{
${ }^{3}$ The Indicator Sub-Group (ISG) of the Social Protection Committee (SPC) has defined a set of common adequacy indicators within the realm of the Open Method of Coordination in order to monitor the progress towards the agreed streamlined objectives in the field of pensions
} 
For the performance of the tasks defined within this model, several government institutions` data will be used: Burro of Statistics - for the gross and net wage, nominal and real growth rate; Agency for Pension and Disability Insurance that administrates the Pay-asyou-go pillar - for the replacement rates actuarial calculation and formulas for calculating the gross wage; Agency for Supervision of Fully Funded Pension Insurance that supervise the mandatory and voluntary fully funded (second and third) pillar - for the data regarding the contribution percentage, entry fee, management fee and the rate of return for the two private pension funds.

The data for the Benefit ratios, Net and Theoretical Replacement Rates for the period/years previously stated in the model for the selected CEE Countries in this paper are taken from the 2009 OECD Report. In calculation, they use the following assumptions: inflation rate $(2 \%)$, annuity interest rate $(1.7 \%)$, real rate of return $(2.5 \%)$ net of administrative charges and taxes, and real earnings growth ranging from $1.2 \%$ to $2.8 \%$ for different OECD Countries.

Different models of the main schemes for private-sector employees exist for each country. It is assumed that all income during retirement comes from the pension schemes are included in the calculations. Statutory pensions include classical pay-as-you-go schemes (Defined-benefit (DB) or Notional defined contribution (NDC)), and the mandatory Definedcontribution (DC) funded tier of the statutory scheme are existing in some Member States (e.g. BU, EE, LT, LV, HU, PL, RO, SK and SE).

\section{Methodology}

We only take the PAYG system in consideration when calculating the pension benefits for employees remaining in the first pillar and for those entering the reformed pension system 
both mandatory pension schemes (PAYG and fully funded pension system) are used. In this research, we neglected the voluntary pension system for the insignificant role in providing retirement incomes in Macedonia.

1. In order to calculate the Benefit ratio for 2060 the actuarial projection for the old-age, early pensions, survivors, and disability pensions will be used (FPID Report, 2010), and then this ratio will be compared with the one for 2007 which is the first year of the reformed pension system in Macedonia. We will also conduct a comparative analysis with the available data for the Benefit Ratios already calculated in the OECD 2009 Report for the selected CEE countries.

2. In order to compare those employees who stayed in the pay-as-you-go system and those who enter the reformed pension system for the period 2006-2046, we use the calculations for the Net Replacement Rate. Net Replacement Rate will be calculated as:

$$
\mathrm{NRR}=\frac{\mathrm{NP}}{\mathrm{NW}}
$$

Where, NP is the net pension (pension, tax deducted), and NW is the net wage (gross wage minus contributions, tax deductions and taxes).

For those who stayed in the PAYG system, according to the current legislated policy solutions - the Law on Pension Insurance and Disability, pension replacement rate is $72 \%$ in 2046 (we use only this scenario in the comparative analysis because the same replacement rate is valid for different level of earnings). We will adjust this replacement rate by the tax rate of $10 \%^{4}$. For those who enter the reformed pension system NRR will be calculated as a sum of the replacement rate in the first pillar (maximum $30 \%$ for contributing 40 years minus tax rate of 10\%), and the replacement rate in the second

\footnotetext{
${ }^{4}$ Macedonia have flat tax rate of $10 \%$
} 
pillar (mandatory pension schemes). Calculation of the replacement rate for the second pillar is according to the following methodology:

We use wage real growth rate of $2.01 \%$ for the period $2006-2046$ calculated as an average rate for the period 2000 - 2006. The real rate of return of $2.25 \%$ in the second pillar we calculate as an average nominal rate of return gained by the two private pension funds, for the entire operating period $(2006-2011)^{5}$, and adjusted for the average inflation rate of $2.15 \%$ in Macedonia for the period $2002-2011$. The pension funds during this period have been investing mainly in the local government bonds and bank deposits. Appendix No. 1 shows the detailed structure of the pension funds investments. For the calculations of the contribution fee, entry fee, management fee and tax rate, we use currently legislated reforms policy solutions. The total pension contribution fee is $18 \%$ on the gross wage, where $65 \%$ remains in the first pillar and $35 \%$ goes to the second pillar (or $6.3 \%$ from the gross wage). The entry fee is $4 \%$ and the management fee calculated on yearly basis for the accumulated assets is $0.6 \%$. We use monthly data when computing in our model. Macedonian pension funds` fees are among the highest in the selected CEE countries ${ }^{6}$ : Poland $7 \%(3.5 \%$ by 2014$)$, Hungary $4.5 \%$, Slovakia $1 \%$ and Bulgaria 5\%. Taking in consideration that the entry fee is $4 \%$ and the real rate of return is only $2.25 \%$ for the operating period, main concern of all involved parties should be to decrease the entry fee and increase the rate of return.

For the basic scenario (average earnings), we use the official published average gross and net wage for 2006. For the calculations of the gross wage in the low and above average wage scenario, we will use 2006 policy solutions:

$$
\mathrm{NW}-\mathrm{TD}=\mathrm{PTW}
$$

\footnotetext{
${ }^{5}$ http://www.mapas.gov.mk/wbstorage/files/Prinos\%20za\%20na\%20Veb\%202011_zadolzitelni.pdf

${ }^{6}$ ILO (2012) Guide for Your Rights for Pensions
} 
Where the NW is the average Net wage for 2006 of $13.490 \mathrm{MKD}$, TD is the tax deduction and for 2006 is a constant of 2.966 MKD, and PTW is the Pre Tax Wage.

$$
\mathrm{NW}+\mathrm{PTW} * \mathrm{PTI} /(100 \%-\mathrm{PTI})=\mathrm{GW} \mathrm{I}
$$

Where PTI is Personal Tax Income for 2006 of 15\%, and GW I is Gross Wage I.

$$
\mathrm{GW} \mathrm{I} * 100 /(100 \%-\mathrm{PI}-\mathrm{HI}-\mathrm{E})=\mathrm{GW} \text { II }
$$

Where PI is the percentage contribution for pension insurance of $21.2 \%$ for $2006, \mathrm{HI}$ is the percentage contribution for Health Insurance of $9.2 \%$ for 2006 , E is the percentage contribution for Employment of $1.6 \%$ for 2006, and GW II is the Gross Wage that according to the calculation is 22.950 MKD.

For a Net Wage of $6.745 \mathrm{MKD}$ (50\% of the average net wage) calculated Gross Wage is $10.900 \mathrm{MKD}$, and for the Net wage of 20.235 MKD (150\% of the average net wage) calculated Gross Wage is 34.239 MKD.

From the collected contribution of $6.3 \%$ from the monthly gross wage, private pension funds charge $4 \%$ entry fee, as stated before. For capitalization of the accumulated assets, we use the monthly real rate of return of $0.1875 \%$ (2.25\% annually), and $0.05 \%$ ( $0.6 \%$ annually) - the charge of monthly management fee. The calculations are made on monthly basis for the period of 40 years, and the accumulated assets are transformed in monthly pension annuities using the monthly interest rate of $0.14167 \%$ (1.7\% annually) and 191 month (15.91 years - the life expectancy of a man at the age of retirement). The Net Replacement Rate is calculated as a ratio between the monthly net pension (monthly pension annuity minus the tax of 10\%) and the monthly average net wage for the period 2006-2046 (as given in the formula above).

We will then perform comparative analysis on the available data for the Net Replacement Rates already calculated in 2009 OECD Report for the selected CEE countries. 
3. For the current Theoretical Replacement Rate i.e. TRR for the period 1966-2006, we will use legislated policy solutions for the period before 2006. According to article 33 from the Law on Pension Insurance and Disability, for the current employees/pensioners in the first pillar of the Pension system, the replacement rate is $80 \%$, and will be reducing in the next forty years to $72 \%$. For the prospective TRR for the period $2006-2046$, we will use calculations performed for the NRR for the same period.

We will complete the comparative analysis, using data for the TRR in 2009 OECD Report for the selected CEE countries.

\section{Discussion of results}

As previously mentioned in the Model and Data section, the issue of pension system sustainability and pension income adequacy in Macedonian has not been subject of foreign, neither domestic research studies. Thus, this paper focuses on the current and future pensions and the replacement rates, analyzing different scenarios: workers who remain in the pay-asyou-go system and workers who enter the reformed system, with low, average and above average earnings. The results from the calculated and compared indexes are as follows:

1. Benefit Ratio, that measures the evolution of pension expenditures per pensioner in relation to the wage per worker in Macedonia:

Table No. 1 Macedonian Pension System Benefit Ratios (2007 - 2060)

\begin{tabular}{|c|c|c|}
\hline Year & Benefit Ratio (In \%) & Change to base scenario (In \%) \\
\hline 2007 & 50,50 & $/$ \\
\hline 2060 & 41,08 & $-19 \%$ \\
\hline
\end{tabular}

Source: Report on Macedonian Pension System with actuarial projections p. 38 
Changes in the Benefit Ratio for the selected CEE countries:

Table No. 2 Selected CEE Countries Benefit Ratios (2007 - 2060)

\begin{tabular}{|l|c|c|c|}
\hline \multirow{2}{*}{ Country } & \multicolumn{3}{|c|}{ Benefit Ratio (in \%) } \\
\cline { 2 - 4 } & 2007 & 2060 & Change \\
\hline Poland & 56,2 & 25,8 & $-54 \%$ \\
\hline Hungary & 38,9 & 35,8 & $-8 \%$ \\
\hline Slovakia & 45,2 & 33,1 & $-27 \%$ \\
\hline Bulgaria & 44,4 & 35,6 & $-20 \%$ \\
\hline
\end{tabular}

Source: 2009 Ageing Report p. 289 by EU Commission

The Benefit Ratio is declining in all examined countries showing fall of the public pensions in relation to the wages. It is a result of reformed measures for providing longterm financial sustainability of a public system. These results will lead to relatively increased poverty of older people in the future, which will require government help in a form of a social assistance. In the reformed pension systems in all countries elaborated in this paper, expenditures from the public pillar will be lower in the future. This is quite strong in Poland (-54\%) and Slovakia (-27\%), moderate in Macedonia (-19\%) and Bulgaria (-20\%), and low in Hungary (only $-8 \%$ ). The question that arises is will the mandatory private pillar balance the decline in the public pillar. According to the findings in this paper, mandatory private pension schemes except for Poland should offset the shortfall in the public pillar. If not taken policy measures to improve the adequacy in Poland, future retirees will be poorer.

2. Net Replacement Rate as previously stated, measures the impact of pension reforms to the structure of future pension system, for low, average and above average workers wage. As a ratio between the net pension (pension, tax deducted), and the net average wage calculated for 40 years, this paper provides the following results: 
Table No. 3 Macedonian Pension System Net Replacement Rates (2006 - 2046)

\begin{tabular}{|l|lc|c|}
\hline \multicolumn{1}{|c|}{ Scenario } & \multicolumn{2}{|c|}{ Net Replacement Rate (in \%) } & Change in \% \\
\hline Only Pay-as-you-go & $64.8 \quad(100 \%$ from PAYG) & $/$ \\
\hline $\begin{array}{l}\text { Reformed system } \\
50 \% \text { net average wage }\end{array}$ & $61.2 \quad(\max 30 \%$ points from PAYG) & $-5.6 \%$ \\
\hline $\begin{array}{l}\text { Reformed system } \\
\text { net average wage }\end{array}$ & $63.0 \quad(\max 30 \%$ points from PAYG) & $-2.7 \%$ \\
\hline $\begin{array}{l}\text { Reformed system } 150 \% \\
\text { net average wage }\end{array}$ & $62.8 \quad(\max 30 \%$ points from PAYG) & $-3.1 \%$ \\
\hline
\end{tabular}

Source: Law on pension insurance and disability (for the PAYG) and Authors own calculations (for the other three scenarios)

We compare the results for the Macedonian Pension System NRR's with those of the selected CEE countries:

Table No. 4 Selected CEE Countries Net Replacement Rates (2006 - 2046)

\begin{tabular}{|l|c|c|c|c|c|c|c|c|c|}
\hline \multirow{3}{*}{ Scenario } & \multicolumn{3}{|c|}{ Only Pay-as-you-go } & \multicolumn{3}{c|}{ Reformed system } & \multicolumn{3}{c|}{ Change (in \%) } \\
\cline { 2 - 11 } & $50 \%$ & $\begin{array}{l}\text { Aver. } \\
\text { Wage }\end{array}$ & $150 \%$ & $50 \%$ & $\begin{array}{c}\text { Aver. } \\
\text { Wage }\end{array}$ & $150 \%$ & $50 \%$ & $\begin{array}{c}\text { Aver. } \\
\text { Wage }\end{array}$ & $150 \%$ \\
\hline Poland & 97.1 & 76.9 & 69.7 & 74.4 & 74.9 & 75 & -23 & -3 & 8 \\
\hline Hungary & 85.9 & 83.2 & 79.1 & 94.3 & 105.5 & 99.2 & 10 & 27 & 25 \\
\hline Slovakia & 76.4 & 75.9 & 52.2 & 66.3 & 72.7 & 74.9 & -13 & -4 & 43 \\
\hline
\end{tabular}

Source: Pension at a glance 2009 OECD Report p. 80

Net Replacement Rates can be helpful when analyzing the redistributive aspects of the pension system. Elaborated countries in this paper, according to the calculated results, are countries that strengthening links between contribution and benefits, i.e. pensions in retirement and earnings during employment (OECD, 2009). This means that in those countries the system is rather fair then redistributive, which make concerns regarding the adequacy of future pensions, especially for low earners. With another words, the system is stimulating the employers and employees to declare and paid maximum contributions according to the job position, sector and industry. In Poland, there is a big decline in the pensions for low earners of $-23 \%$, fall of only $3 \%$ for average earners and $8 \%$ rise for high earners. For Slovakia and Hungary, the change is even more significantly. Low earners assume difference of $-13 \%$ and $+10 \%$ respectively, while the above average earners expect 
$+43 \%$ and $+25 \%$ respectively. Macedonia tends to make across-the-board cuts in pensions, highest for the low earners $-5.6 \%,-3.1 \%$ for above the average earners and only $-2.8 \%$ for average earners. This system solution, of close NRR's, and small but still fall in NRR's can be anticipated as a policy for providing future equality between deferent earners (at least in rational numbers) and providing system financial sustainability.

3. The changes expected in the average first pension as a proportion of the average wage or so called the Theoretical Replacement Rate, are given in the table below:

Table No. 5 Macedonian Pension System Theoretical Replacement Rates (2006-2046)

\begin{tabular}{|l|c|c|c|}
\hline \multicolumn{1}{|c|}{ Scenario } & Period & $\begin{array}{c}\text { Theoretical } \\
\text { Replacement Rates }\end{array}$ & $\Delta$ (in \% points) \\
\hline Pay-as-you-go & $1966-2006$ & $72.0(\max )$ & $/$ \\
\hline Reformed system & $2006-2046$ & 51.8 & $-19,2 \%$ points \\
\hline
\end{tabular}

Source: Authors own calculations

We compare the results for the Macedonian Pension System TRR's with those for the selected CEE countries:

Table No. 6 Selected CEE Countries Theoretical Replacement Rates (2006 - 2046)

\begin{tabular}{|l|c|}
\hline Scenario & $\begin{array}{c}\text { Change in TRR in } \\
\% \text { point }(2006-2046)\end{array}$ \\
\hline Poland & $-19 \%$ points \\
\hline Hungary & $+5 \%$ points \\
\hline Slovakia & $+2 \%$ points \\
\hline Bulgaria & $+15 \%$ points \\
\hline
\end{tabular}

Source: The 2009 Indicator Sub-Group (ISG) of the Social Protection Committee (SPC) Report p. 17.

This is another indicator used in the analysis of the adequacy of pension benefits to future retirees - expected changes in the average first pension received as a proportion of the average wage. Results indicates that for Poland and Macedonia the TRR is projected to decline over the coming period almost the same (-19\% points), Hungary and Slovakia will not changed significantly ( $+5 \%$ points; $-5 \%$ points), while the TRR in Bulgaria suggest immense increase of $15 \%$ points. 


\section{Conclusions and Recommendations}

In the past several years as a response to the global financial crisis, the CEE countries started remodeling the previously reformed private pension systems with an effort to decrease the fiscal deficits.

The initial pension reform implementation made expectations for significant benefits such as increased labor participation, higher saving rates and faster capital market development. However, these benefits are not visible for the time being. The long-term projections show that the reduced relative levels of public pensions will affect the future sustainability of the pension system. The current analysis of the adequacy of the pension benefits shows that the ratio between the average public pension benefits and the wages in the selected CEE countries is higher than it will be in the future. This implies that the future pensioners will experience a relative deterioration in living standards vis-à-vis the working force, unless their average working live is prolonged.

All these assumptions lead to one general conclusion that the pension system structure needs reevaluation in order to find the optimal structure, taking into account demographics, labor market and socio-economic developments. Calculated reduction in the replacement rates in this paper shows that the reform is not going to create adequate pension benefits. The actual situation of the labor market is changed (temporary and part-time jobs, self-employment) and makes it difficult to complete the lifetime employment that needs to be fulfilled for adequate retirement incomes. Not to forget that calculations for the replacement rates are for a full career employee and still they are not adequate. Therefore, there is a need for additional saving funds apart from the state pensions in order to sustain the current quality level of living when people retire. The government and the regulatory bodies should work together to improve financial education and change behavior towards longer working life and savings to generate greater retirement income. 
The comparative analysis indicates relative variation within the selected CEE countries in providing adequate pension benefits and pension system sustainability. Moreover, the similar pension systems' history and the ongoing global financial crises consequences make it difficult to find proper solutions for the problems within the pension systems in each country. In order to avoid any social imbalance and fiscal distortions policy makers should maintain balance between the adequacy of the future pension benefits and the pension system sustainability. According to its pension system characteristics, each country should use the best of the scientific and empirical experience to continue with the reforms towards the realization of the previously mentioned goals.

Since 2006 (the beginning of the three pillars pension system) Macedonia started facing fiscal problems in terms of covering the public pension expenses, due to the decreased level of total pension contributions collected in the state pension fund. Even though these measures endanger the fiscal stability on short term, it seems only reasonable path towards the longterm pension system sustainability. The changes in the economic and demographic factors in the future will provoke extended fiscal problems, if not implemented any of the reforms.

Policy makers' main concern in the future should be to increase the employment. In doing so, policy makers should not motivate the early retirement. Although it creates opportunities for new employment, the higher expenses will burden the pension system even more.

Despite the previous increase of the retirement age limits, any further extensions will not favor towards decreasing the unemployment. However, following the other European countries experience, where the retirement age is increasing taking into account the extended life expectancy, we recommend the same for Macedonia in near future.

The final asset balance for the pension benefit depends of the contributions flaw, the administrative fees and the rate of return. Therefore increased contributions, reduced pension 
funds administrative fees, and increased rate of return will lead towards lower costs and pensions that are more adequate.

We used different variables for determining the ratios, such as the inflation rate, contribution fee, entry fee, management fee and the rate of return. However, different results may occur in case other estimated values are used. It is important to say that we use real data to determine the variables, although they refer only to a short time period of the private pension fund s operation.

This research can be extended and updated, and use for measuring the specific implication in the future pension system`s modification, or can be use as an useful guidance to pension related issues for the policy makers.

\section{References}

Ageing Working Group (AWG) Economic Policy Committee, (2009). Updates of Current and Prospective Theoretical Pension Replacement Rates 2006-2046, ISG 2009 Report. Retrieved from http://ec.europa.eu/social/BlobServlet?docId=4305\&langId=en

Antonio, A. E. (2009). Measurement issues for adequacy comparisons among pension systems. ENEPRI Research report no. 64. Retrieved from http://aei.pitt.edu/10746/

Aslund, A. (2011). Is the catching-up process in central and eastern Europe sustainable? Conference on European Economic Integration at the Austrian National Bank, Vienna, Austria, November 21-22, 2011. (Draft November 12, 2011). Retrieved from http://www.oenb.at/de/img/aslund_onb_catching_up_process_nov_12_2011_stand_1 4112011_tcm14-241451.pdf 
Behrman, J. R., Maria, C. C., Olivia, S. M., Javiera, V., \& David, B. (2011). First-Round Impacts of the 2008 Chilean Pension System Reform. PARC Working Paper Series, WPS 11-01. Retrieved from http://repository.upenn.edu/parc_working_papers/33

Bernhard, E. (2011). Reforms of Pension System in the light of socioeconomic interdependencies. $9^{\text {th }}$ Annual ESPAnet Conference Sustainability and transformation in European Social Policy. Valencia, Spain. September 8-10, 2011

Retrieved from

http://espanet2011.files.wordpress.com/2011/08/st15a_ebbinghaus_op.pdf

Chybalski, P. (2010). The Resilience of Pension Systems in the CEE Countries to Financial and Economic Crisis: the Need for Higher Diversification. Conference Proceedings, $13^{\text {th }}$ International Conference of Finance and Banking, Ostrava, Czech Republic, October 12-13, 2011. pp. 257 - 267. Retrieved from

http://www.opf.slu.cz/kfi/icfb/proc2011/pdf/22_Chybalski.pdf

Clark, G. L., \& Whiteside, N. (2005). Pension security in the 21st Century: Redrawing the public-private debate. Oxford, Oxford University Press.

Corbanese, V. (2011). Supporting Strategies to recover from the Crisis in Croatia, the Former Yugoslav Republic of Macedonia and Serbia, Cross-Country Report. International Labour Organization working paper. Retrieved from http://www.ilo.org/budapest/what-we-do/publications/WCMS_166982/lang-en/index.htm

David, N. (2011). Reforming Pensions in the EU: National Policy Changes and EU Coordination European Social Observatory (OSE). Retrieved from http://www.ose.be/files/publication/dnatali/Natali_2011_-FLCaballero_251011.pdf

Delia, V. (2011). Pension Reforms in Emerging Europe: The Uncertain Road Ahead, IMF Country Report No. 11/167. Retrieved from 
http://www.imf.org/external/pubs/ft/scr/2011/cr11167.pdf

Draxler, J., \& Mortensen, J. (2009). Towards sustainable but still adequate pension in the EU. Adequacy of Old-Age Income Maintenance in the EU (AIM) Project. ENEPRI Research Report No. 67. Retrieved from http://www.enepri.org

Ervik, R. (2005). The battle of future pensions, Global Accounting Tools, International Organizations and Pension Reforms. Global Social Policy, 5(1), 29-54.

European Commission. (2009). Economic and Budgetary Projections for the EU-27 Member States (2008-2060). 2009 Ageing Report - Joint Report European Economy 2/2009. Office for Official Publications of the European Communities - Luxembourg. Retrieved from http://ec.europa.eu/economy_finance/publications/publication14992_en.pdf

European Commission. (2010). Europe 2020 - A European strategy for smart, sustainable and inclusive growth. Communication from the Commission. Brussels, Belgium, March 3, 2010 Retrieved from

http://eunec.vlor.be/detail_bestanden/doc014\%20Europe\%202020.pdf

European Commission. (2010). Towards adequate, sustainable and safe pension European Pension Systems. Green Paper SEC (2010)830. Brussels, Belgium, July 7, 2010 Retrieved from http://ec.europa.eu/social/BlobServlet?docId=5551\&langId=en European Commission - Federal Public Service Social Security. (2010). Assuring adequate pensions for all European citizens. Background paper from Belgian Presidency of the Council of the European Union. Brussels, Belgium, 2010. Retrieved from http://www.socialsecurity.fgov.be/eu/en/agenda/06-08_09_10.htm

European Commission - The Indicator Sub-Group (ISG) of the Social Protection Committee (SPC). (2009). Updates of Current and Prospective Theoretical Pension Replacement Rates 2006-2046. 2009 Report. Retrieved from 
http://ec.europa.eu/social/main.jsp?langId=en\&catId=752\&newsId=551\&furtherNews $=$ yes

European Commission. (2012). An Agenda for Adequate, Safe and Sustainable Pensions. White paper, Brussels, Belgium. Retrieved from http://www.cicero-group.com/wpcontent/uploads/2012/02/Pensions-White-Paper-Special1.pdf

European Federation for Retirement Provision. (2011). Pensions MEPs set out clear recommendations on Pension. Press Statement EC Green Paper. Retrieved from http://www.efrp.org/LinkClick.aspx?fileticket=T1GD12yinWM\%3D\&tabid=1402

Fund for Pension Insurance and Disability. (2010). Report on Macedonian Pension System with Actuarial Projections. Retrieved from http://www.piom.com.mk/informacii/statistika/40.html

Guardiancich, I. (2008). The sustainability of pension reforms in Central, Eastern, and Southeastern Europe, South-East Europe Review for Labour and Social Affairs, 11(2), $185-197$

Heise, A. \& Lierse, H. (2011). Budget Consolidation and the European Social Model, "The Effects of European Austerity Programmes on Social Security Systems”, Friedrich Ebert Stiftung. Retrieved from http://library.fes.de/pdf-files/id/ipa/07891.pdf

Hirose, K. (2011). Pension reform in Central and Eastern Europe: in times of crisis, austerity and beyond. International Labour Organization working paper, Decent Work Technical Support Team for Central and Eastern Europe. Budapest, Hungary, 2011, 1 Retrieved from http://www.ilo.org/public/english/region/eurpro/geneva/download/pension_reform_ce e.pdf 
Hlaváč, J. (2011). Financial performance of the Czech private pension scheme: Its current position and the comparison with other CEE countries, IES Working Paper 9/2011. IES FSV. Charles University. Retrieved from http://ies.fsv.cuni.cz

Jarrett, P. (2011). Pension reform in Poland and elsewhere: the view from Paris. Case Network Studies and Analysis No. 425. Center for Social and Economic Research Warsaw, Poland. Retrieved from http://kms1.isn.ethz.ch/serviceengine/Files/ISN/132679/ipublicationdocument_singled ocument/b323bf86-f112-4570-b074-ee9a1e37fc05/en/2011_425.pdf

Law on pension insurance and disability (Public Gazette of Republic of Macedonia No. 80/1993) ${ }^{7}$ Retrieved from

http://www.sakamznammozam.gov.mk/clientControls/upload/Zakon\%20za\%20penzis ko\%20i\%20invalidsko\%20osiguruvanje.pdf

Miloş, L. R. \& Miloş, M. C. (2011). Impact of the financial crisis on the pension system reform. Lessons from Central and Eastern European countries. Retrieved from http://www.opf.slu.cz/kfi/icfb/proc2011/pdf/36_Milos.pdf

Müller, K. (2001). The political economy of pension reform in Eastern Europe. International Social Security Review. 54(2-3), 57-79

OECD (2009), Pensions at a Glance 2009: Retirement-Income Systems in OECD Countries. Online Country Profiles, including personal income tax and social security contributions

Retrieved from www.oecd.org/els/social/pensions/PAG

OECD (2011), Pensions at a Glance 2011: Retirement-Income Systems in OECD and G20 Countries ( $4^{\text {th }}$ ed.).

\footnotetext{
${ }^{7}$ The Law on pension insurance and disability had 36 changes, adds and court decisions from 1993 until today
} 
Retrieved from www.oecd.org/els/social/pensions/PAG

Orenstein, M. A. (2011). Pension Privatizing in Crisis: Death or Rebirth of a Global Policy Trend? International Social Security Review, 64(3), 65-80

Pension fund assets climb back to pre-crisis levels but full recovery still uncertain, Pension Markets in Focus, July 2011, OECD Report, Issue 8

Tuesta, D. (2011). A review of the Pension Systems in Latin America, BBVA Research Working Papers Number 11/15, Madrid, Spain. April 18, 2011

Retrieved from http://www.bbvaresearch.com/KETD/fbin/mult/WP_1115_tcm348255095.pdf?ts=2352011

UNDP. (2011). Economic Crisis Responses from a Governance Perspective in Eastern Europe and Central Asia: Regional Report, Regional Centre for Public Administration Reform. March, 2011

Retrieved from http://issuu.com/undp_in_europe_cis/docs/econ_crisis_gov

Weyland, K. (2005). Theories of policy diffusion: Lessons from Latin American pension reform, World Politics - Cambridge journals online, 57(2), 262-295

World Bank. (2011). The Employment, Skills and Innovation, Agenda A, World Bank Technical Note Europe 2020. Retrieved from https://ec.europa.eu/employment_social/anticipedia/document/showFile.do?id=3111\& idDigest=1ddc45549c1613a8e8970774fe3d59dfc7be8910

Zaidi, A. (2010). Sustainability and adequacy of pensions in EU countries: A cross-national perspective, Conference under the Belgian Presidency of the Council of the European Union, Assuring Adequate Pensions and Social Benefits for All European Citizens, Liège, Paris. Retrieved from http://www.euro.centre.org/data/1284987555_57246.pdf 


\section{Tables}

Table No. 1 Macedonian Pension System Benefit Ratios (2007 - 2060) . . . . . . . . . 13

Table No. 2 Selected CEE Countries Benefit Ratios (2007 - 2060) . . . . . . . . . . . .14

Table No. 3 Macedonian Pension System Net Replacement Rates (2006 - 2046). . . . . . 15

Table No. 4 Selected CEE Countries Net Replacement Rates (2006-2046). . . . . . . . . .15

Table No. 5 Macedonian Pension System Theoretical Replacement Rates. . . . . . . . . . 16

Table No. 6 Selected CEE Countries Theoretical Replacement Rates. . . . . . . . . . . . 16

Appendix No. 1

\begin{tabular}{|l|c|c|c|c|c|c|}
\hline \multicolumn{1}{|c|}{ Year } & 2006 & 2007 & 2008 & 2009 & 2010 & 2011 \\
\hline \multicolumn{1}{|c|}{ ASSET CLASS* } & & & & & & \\
\hline Shares of domestic issuers & 3.8 & 18.9 & 7.1 & 4.8 & 3.2 & 3.5 \\
\hline Bonds of domestic issuers & 72.4 & 59.8 & 44.2 & 57.5 & 53.7 & 61.7 \\
\hline Short term domestic assets & 6.9 & 0.0 & 3.8 & 0.0 & 0.2 & 0.0 \\
\hline Bank deposits (domestic) & 16.9 & 18.5 & 41.9 & 35.1 & 31.6 & 18.6 \\
\hline Cash & 0.0 & 0.0 & 0.5 & 0.8 & 0.3 & 0.3 \\
\hline Shares of foreign issuers & 0.0 & 2.7 & 1.7 & 1.1 & 2.1 & 2.6 \\
\hline Bonds of foreign issuers & 0.0 & 0.0 & 0.0 & 0.0 & 3.0 & 0.0 \\
\hline Foreign investment funds & 0.0 & 0.2 & 0.4 & 0.3 & 5.9 & 13.3 \\
\hline
\end{tabular}

